\title{
MEGJEGYZÉSEK EMBEY-ISZTIN ANTAL AZ ÉREM MÁSIK OLDALA CÍMÜ TANULMÁNYÁHOZ
}

\section{REMARKS TO ANTAL EMBEY-ISZTIN'S PAPER THE OTHER SIDE OF THE COIN}

\author{
Bujtor László \\ habilitált egyetemi docens, Pécsi Tudományegyetem \\ Ibujtor@gamma.ttk.pte.hu
}

\begin{abstract}
ÖSSZEFOGLALÁS
A földi élet kialakulásától az intelligencia megjelenéséig vezető út kétségtelenül hosszú, kacskaringós és véletlenekkel tarkított. Habár az élő rendszerek kialakulását még nem értjük, az már körvonalazódik, hogy az élet megjelenése szinte törvényszerű egy csillag körül a lakhatósági zónában keringő Föld-szerủ bolygó esetében. Ami ezután következik, az már jóval inkább esetleges, és - földi típusú életet feltételezve - számos további feltétel meglétét igényli. Az Embey-lsztin Antal által felsorolt feltételeket újabbakkal egészítjük ki: szükséges egy külső "söprögető" gázbolygó, mely nagy tömege által magához vonzza a naprendszerek pereme felől érkező üstökösöket, aszteroidákat. A lemeztektonika nemcsak azért szükséges, hogy temperálja a bolygót, hanem azért is, mert a folyamatosan változó felszín új meg új geotópokat teremt. Az eukarióta sejt önmagában nem lett volna elegendő a nagyméretű állatok és növények világának kialakulásához, további feltétel a bonyolult sejtszervecskék megszerzése (endoszimbiózis), és legalább ennyire fontos a szexuális szaporodás megjelenése mint a sokszínűség megteremtője és fenntartója. És ezen újabb feltételek teljesülése mellett is valószínű, hogy az első megpillantott idegen életjelenség nem élőlény, hanem annak fosszíliája lesz majd.
\end{abstract}

\section{ABSTRACT}

The path from the formation of life on Earth to the emergence of intelligence was undoubtedly long, devious, and full of coincidence. Although we do not understand the formation of life yet, however, it seems to be plausible that in the case of an Earth-like planet orbiting in the Goldilocks-zone the appearance of life is predictable and almost necessary. After this everything is contingent, and regarding the Earth-type life forms, requires other important assumptions. The conditions listed by Embey-Isztin need to be augmented: a large mass, outer orbiting gas giant is needed to sweep and collect those bodies that arrive from the outer space or the edge of its solar system. The plate tectonics is not only needed to temper the climate, but in addition it provides continuous renewal to the crust and continuously creates new geo-topes. The eucaryote cell itself would not have been enough to form a stem-group for emerging the large-sized plants and animals. Further important conditions are the acquisition of the complicated organs 
inside the living cell acquired via endosymbiosis. Sexual reproduction, however, is as important as all the previous ones. It provides and maintains the basis for versatility. Considering all these conditions it is very much probable that the first alien life form to be encountered by humans will be a fossil.

Kulcsszavak: Pangea, geodiverzitás, SET-elmélet, kihalási esemény, evolúció, lemeztektonika, idegen létformák

Keywords: Pangea, geodiversity, SET theory, extinction events, evolution, plate tectonics, alien life

Nagy érdeklődéssel olvastam Embey-Isztin Antal értekezését az intelligens élet földi kifejlődésének feltételeiről és ezen feltételek diszkussziójáról. Fejtegetésével alapvetően egyetértek, ám néhány tételével vitába szállok, illetve új aspektusok bemutatásával árnyalni kívánom azt.

Az a kérdés, hogy emberi intelligenciánkkal és technológiai fejlettségünkkel egyedül vagyunk-e ebben a galaxisban (vagy akár az egész Univerzumban), régóta foglalkoztatja az emberi elmét. Itt csak a hasonló indíttatású, szintén paleontológus Simon Conway Morris remek könyvére utalok (2003). Megjegyzéseim elsősorban Embey-Isztin Antal lemeztektonikai és föleg evolúciós megállapításaira vonatkoznak, melyeket a hivatkozott cikk (Embey-Isztin, 2020) alapján, a szövegbeli megjelenés sorrendjében mutatok be.

1. „A lemeztektonika egy visszacsatolásos mechanizmussal temperálja a Földet.” Az állítással természetesen egyetértek, ám a lemeztektonika további - az élet fejlődése/változása szempontjából legalább ennyire fontos - jelenségekkel járul hozzá a földi élet alakulásához. Ezek az alábbiak:

a) A szuperkontinens (Pangea) konfiguráció ciklikus kialakulása és megszünése

A lemeztektonika megjelenése és folyamatai csaknem egyidősek a szilárd, szárazföldi kéreg megjelenésével. A vándorló, ütközö, összeolvadó, majd feldarabolódó kontinentális kéregrészek legutóbb mintegy 250 millió évvel ezelőtt rendeződtek egyetlen szuperkontinenssé, amit Pangeának hívunk. Ám nem ez volt az egyetlen szuperkontinens a földtörténet során. Jóval korábban, mintegy egymilliárd évvel ezelőtt már létezett egy szuperkontinens, amit Rodiniának neveztek el. Semmi sem zárja ki annak a lehetőségét, hogy az ennél is távolabbi múltban létezett egy (több?) további szuperkontinens, ám erre nincs geológiai bizonyíték. Mégis csupán az utolsó, a Pangea-konfiguráció az, amelynek kialakulásához az egyik legnagyobb kihalási eseményt társítjuk. Miért jár együtt a szuperkontinens konfiguráció létrejötte globális kihalással mind a tengeri, mind a szárazföldi élőlények számára? A válasz 
igencsak összetett, és itt csak egyetlen, kizárólag a lemeztektonikához kötödő tényezőt szeretnék kifejteni, amelyet az 1. ábra mutat be. A szuperkontinens létrejöttével a kontinensek területe nem, ám partvonaluk teljes hossza drámai csökkenésen megy át: modellünk esetében a normál konfiguráció esetén mérhető hosszúság 38\%-ára zsugorodik. Más szóval, a sekélytengeri, part menti élőhelyek 62\%-a egyszerüen eltünik! Ez önmagában is jelentős kihaláshoz vezető jelenség.

b) A geodiverzitás hatása a biodiverzitásra

Amint a Pangea-konfiguráció megszűnik, és felbomlik a szuperkontinens, nemcsak a szárazföldi légköri és a tengeri vízáramlási rendszerek változnak meg, hanem új partvonalak alakulnak ki, új sekélytengeri környezetek jelennek meg, a növekvő geodiverzitás tehát „megágyaz” a biodiverzitás ugrásszerü növekedésének. A földi élet sokszínüségének és változatosságának tehát támogatói, hajtóeröi a folyamatosan változó, alakuló geokörnyezetek is, melyek kialakulásáért végső soron a lemeztektonika felel. Ezt a folyamatos megújulást kizárólag a lemeztektonika adja a földi bioszférának.

A lemeztektonika komplex folyamatai tehát nemcsak a földi klíma „temperálásában" játszanak szerepet, hanem legalább olyan jelentős szerepük van a földi élet változatosságának kialakításában, $\mathrm{s}$ bár olykor-olykor ez a változás drámai kihalásokban játszik szerepet (lásd perm-triász kihalási esemény), alapvetően a folytonosan megújuló geokörnyezetek a biodiverzitás fenntartásának nélkülözhetetlen kellékei ezen a bolygón.
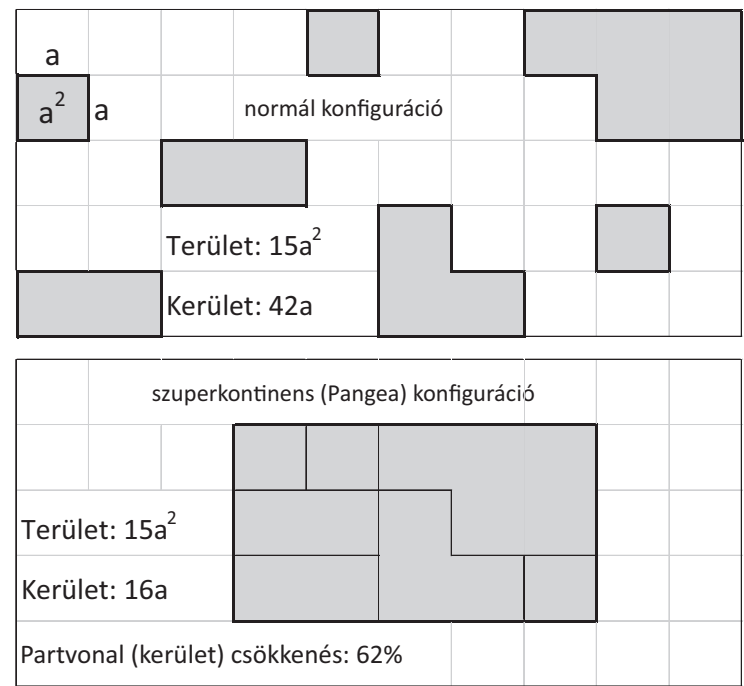

1. ábra. A szuperkontinens és normál kontinens konfiguráció összevetése 
Elképzelt bolygónk felszínén hét kontinens található, melyek a teljes bolygófelszín 30\%-át borítják. Amennyiben az elképzelt bolygónkon müködö lemeztektonikai folyamatok hatására ezek a kontinensek szuperkontinenssé állnak össze (= Pangea-konfiguráció), úgy felületük változatlan marad, ám partvonalaik (= kerületük) teljes hossza az eredeti $38 \%$-ára csökken. Önmagában ez a folyamat is globális kihalási eseményhez vezet, hiszen az eredeti sekélytengeri (= partvonalközeli) élőhelyek több mint fele megsemmisül.

2. „Az eukarióta evolúciós forradalom volt a döntő előrelépés, amely az állatvilág megjelenésében kulminált."

A megjegyzéssel ebben a megfogalmazásban nem értek egyet. Az eukarióta sejt (= sejtmagot tartalmazó sejt) megjelenése önmagában nem lett volna elegendő ahhoz a sokszínü, bonyolult és soksejtes élővilágnak a kifejlődéséhez, amint ezt a fenti mondat sugallja. Egyéb, legalább ennyire fontos jelenségek müködtek még közre abban, hogy a többsejtủ, nagy méretủ élőlények (állatok és növények) megjelenjenek a tengerekben, majd hosszú fejlődést követően a szárazföldre lépjenek.

a) Lynn Margulis SET-elmélete és következményei

A sorozatos endoszimbiózis elmélet (SET) plauzibilis magyarázatot ad az eukarióta sejt kialakulására. Lynn Margulis elméletére ma már meggyőző bizonyítékaink vannak (Gray, 2017), és tudjuk, hogy az eukarióta sejt kialakulásában a különféle sejtorganellumok mint a mitokondriumok és kloroplasztiszok eredetileg aerob baktériumok és cianobaktériumok bekebelezésével alakultak ki. Ezt az elméletet a genetikai vizsgálatok igazolták, és ezek a sejtszervecskék az állati és növényi nagy méretü élőlények kialakulásának előfeltételei közé tartoznak.

b) A szex megjelenése és következményei

Ugyancsak ilyen előfeltétel a szex megjelenése a sejtmagvas élőlények szaporodásában. Ez legalább olyan fontos tényező, mint a sejtmag és a sejtszervecskék megjelenése. A szexuális szaporodás biztosítja az állati és növényi sokszínűséget, sokféleséget, amely aztán képes tartalommal megtölteni a változatos geokörnyezeteket. Szexuális szaporodás nélkül is lenne élet a Földön, de egészen biztos, hogy nem lenne ennyire sokszínü, változatos, és még inkább kétséges, hogy az intelligencia megjelenéséhez az aszexuális szaporodásmód elvezetett volna.

3. „A kambriumi robbanás unikum volt a Föld történetében.”

Hivatkozott írásomban (Bujtor, 2020) részletezem, hogy mai tudásunk alapján nem maga a kambriumi életrobbanás a meglepő, azt ma már jóval inkább korábbi folyamatok elkerülhetetlen következményeként látjuk. Sokkal fontosabb tényező volt a kriogén időszak alatti körülmények alakulása, az óceánok oxi- 
géntartalmának növekedése, majd egy valódi nóvum, a ragadozó táplálkozási mód megjelenése Földünkön, mely egy ettől független folyamattal egyesülve vezetett el a kambriumi életrobbanás kiteljesedéséhez: a kriogén időszak végén felolvadó jég megemelte a tengerszintet, új, fénnyel átitatott, langyos vizü sekélytengeri környezetek jöttek létre (geodiverzitás!); mely keretrendszert tekintve törvényszerüen következett be a sekélytengerekben az élet felvirágzása és elburjánzása.

4. „A Naprendszer kialakulását megszámlálhatatlan kisebb-nagyobb test kaotikus mozgása, azok ütközése jellemezte.”

Ezzel is egyetértek, ugyanakkor hiányolom a Jupiter szerepének megemlítését a földi élet megvédése szempontjából. A Shoemaker-Levy 9 üstökös feldarabolódása a Jupiter gravitációs terében, majd az egyes daraboknak a Jupiter légkörébe csapódása drámai példáját adja egy külső pályán keringő óriásbolygó gravitációs szerepének. Amennyiben tehát a földi intelligencia kialakulásának feltételeit kívánjuk összeszedni, egy nagy, a kőzetbolygóhoz képest külső pályán keringő gázbolygót is feltételeznünk kell, amely eltéríti a belső bolygók felé száguldó kisbolygókat és üstökösöket. Persze ez a védelem nem lehet állandó és kizárólagos, ám mégis igen fontos feltétel: a túl gyakran érkező és a földi élet számára olyan pusztítást végezni képes bolygóközi testek, mint amilyen a kréta végi kihalást okozó égitest volt, túl gyakori becsapódása nem tenné lehetővé a magasabb rendü intelligencia kialakulását. Egymást követő két becsapódás között egyszerüen nem lenne elegendő idő arra, hogy az intelligencia megjelenjen.

5. ,[A]z aszteroidabecsapódás [...] esetleges volta [...] a lehető legrosszabb »választás « volt az atmoszféra szennyezése szempontjából."

Az aszteroidabecsapódás véletlenszerüsége elég megdöbbentő kontextusba helyezhetö, ami bizony elgondolkodtató saját létünk és a földi élet esetlegességének szempontjából egyaránt. Egy tavaly a Föld közelében elszáguldott aszteroida sebessége $7,1 \mathrm{~km} / \mathrm{s}$ volt. Amennyiben tehát a kréta végi kihalásban jelentős szerepet játszó aszteroida is hasonló sebességgel érkezett, csupán 7 perccel korábban/később kellett volna érkeznie ahhoz, hogy 3000 km-rel odébb csapódjék Földünknek, az akkori Csendes-óceán mélymedencéjébe, hogy több kilométernyi vízborítottságú óceáni aljzatba ütközzön. Egy ilyen jellegủ becsapódás kimenetele egészen más lett volna...

6. „Az utolsó 550 millió év alatt öt nagy és sok kisebb kihalási esemény volt...” Ezzel a megjegyzéssel nem értek egyet. A kihalások kutatása és a szabályosságok keresése ma már nem gyerekcipőben járó, születő tudományág. John Sepkoski 1970-es évekbeli úttörő munkássága nyomán jobban értjük a kihalásokat. 
Tudjuk, hogy az élet elválaszthatatlan velejárója a kihalás, és ma már azt is tudjuk, hogy Sepkoski kihalásdefiníciójának (Sepkoski, 2001) nem öt nagy és sok kisebb, hanem tizennyolc kihalási esemény felel meg az elmúlt 550 millió évben (Bambach, 2006). Richard Bambach eredeti ábrája a fanerozoikum során 109 olyan kihalási eseményt tüntet fel, amikor az adott kihalási esemény során a vizsgált nemzetségek legalább 10\%-a eltünt. Ami őslénytani-rétegtani megközelítésben nem is meglepö, hiszen a rétegtan tudománya pontosan az ilyen változások dokumentálása révén alakult ki és fejlődött: a földtörténeti idő nagy fordulópontjai (a legutolsó félmilliárd évben legalábbis) szinte kivétel nélkül valamilyen nagy kihaláshoz, a rétegsorban dokumentált ősmaradványok nagyléptékű kicserélődéséhez kapcsolódnak. A kihalások tehát éppolyan természetes részei a földi élet változásának, mint amilyen a fajok keletkezése, a speciáció. Egyik sem folyamatos, graduális esemény, és a véletlennek, a kiszámíthatatlannak óriási szerepe van bennük. Az egyiknél kiváltó ok, a másiknál következmény.

7. „Amennyiben találunk életet a Földön kívül, az valószínüleg valamilyen primitív forma lesz."

Álláspontom szerint sokkal nagyobb lesz a valószínúsége annak, hogy valamilyen élölény fossziliáját találjuk meg elsőként (könnyen lehet, hogy éppen a Marson), nem pedig élőlényt. Ne feledjük, jelenleg a Földünkön élő összes faj mindössze 1\%o-e a valaha élt összes fajnak, a többi 99,99\% mind kihalt! És ha átnézzük az Embey-Isztin Antal írásában részletezett különleges feltételeket, hozzáadva a jelen írásban hozzátett újabbakat, jó eséllyel mondhatjuk: az élet kialakulásának feltételei jóval nagyobbak, mint hosszú távú fennmaradásának, és annak, hogy a folyamatosan fejlődő/változó élet eljut az intelligens lények kialakulásáig.

\section{A 2. ábra, ,a primitív állati élet kialakulásának ideje”.}

Az ábra forrásaként megadott oldal felkeresése nem sikerült, így az eredeti ábrát nem találtam meg. Az ábra mindenesetre azt sugallja, hogy a ,primitív állati élet” valamikor a kambriumi életrobbanással együtt jelent meg. Ez téves. A kriogén időszakot követően már ismerünk többsejtü, bonyolult testfelépítésü lényeket az Ediakara-faunából (például Dickinsonia), melyek már 800-900 millió évvel ezelőtt megjelentek, és igen hosszú időn keresztül virágoztak.

IRODALOM

Bambach, R. K. (2006): Phanerozoic Biodiversity Mass Extinctions. Annual Review of Earth and Plantery Sciences, 34, 1, 127-155. DOI: 10.1146/annurev.earth.33.092203.122654, https://www. researchgate.net/publication/213769252_Phanerozoic_biodiversity_mass_extinctions 
Bujtor L. (2020): A ragadozó táplálkozási mód megjelenése és a fény szerepe a kambriumi életrobbanás elökészítésében. Magyar Tudomány, 181, 2, 222-230. DOI: 10.1556/2065.181.2020.2.8 Conway Morris, S. (2003): Life's Solution: Inevitable Humans in a Lonely Universe. Cambridge: Cambrdige University Press

Embey-Isztin A. (2020): Az érem másik oldala. Magyar Tudomány, 181, 1, 107-115. DOI: 10.1556/2065.181.2020.01.12, https://mersz.hu/dokumentum/matud_734

Gray, M. W. (2017): Lynn Margulis and the Endosymbiont Hypothesis: 50 Years Later. Molecular Biology of the Cell, 28, 10, 1285-1287. DOI: 10.1091/mbc.E16-07-0509, https://www.molbiolcell.org/doi/pdf/10.1091/mbc.e16-07-0509

Sepkoski, J. J. (2001): Mass Extinctions, Concept of. Encyclopedia of Biodiversity, 4, 97-110. DOI: 10.1016/B978-0-12-384719-5.00091-5, https://www.researchgate.net/publication/288177804 Mass_Extinctions_Concept_of 